\title{
Intense ectoenzyme activities associated with Trichodesmium colonies in the Sargasso Sea
}

\author{
Karen M. Orcutt ${ }^{1, *}$, Kjell Gundersen ${ }^{1}$, James W. Ammerman ${ }^{2}$ \\ ${ }^{1}$ Department of Marine Science, University of Southern Mississippi, 1020 Balch Blvd., Stennis Space Center, \\ Mississippi 39529, USA \\ ${ }^{2}$ School of Marine and Atmospheric Sciences, Stony Brook University, Stony Brook, New York 11794-5000, USA
}

\begin{abstract}
Ectoenzyme activities of alkaline phosphatase (APA) and leucine aminopeptidase (LAP) associated with Trichodesmium, a globally significant dinitrogen $\left(\mathrm{N}_{2}\right)$ fixer, were measured on cruises to the Bermuda Atlantic Time-Series (BATS) site. Rates associated with Trichodesmium were compared to microbial enzyme activities in natural seawater between August 1992 and November 1997. Colonies of Trichodesmium function as 'microsites' for ectoenzyme activity and express high rates of APA ( 4 to $66 \mathrm{nmol}$ colony ${ }^{-1} \mathrm{~h}^{-1}$ ) and LAP (53 to $389 \mathrm{nmol}$ colony $^{-1} \mathrm{~h}^{-1}$ ). For Trichodesmium APA, substrate half-saturation constants $\left(K_{\mathrm{m}}\right)$ exceeded surrounding seawater APA by a factor of 20 to 40 times. Overall, the ectoenzyme activity measured in puff shaped colonies of Trichodesmium did not differ significantly from the rates associated with the tuft morphology. Ectoenzyme activites measured in the cyanobacterial consortium did not vary as strongly seasonally as was observed in natural seawater. Elemental ratios of Trichodesmium colonies showed a molar C:N ratio around the Redfield stoichiometry (mean $=6$, range 4 to 7 ) while the C:P ratios were much higher (mean $=513$, range 163 to 1044). Calculated per volume seawater, measured uptake of phosphate and leucine were 4 to 6 orders of magnitude lower in Trichodesmium

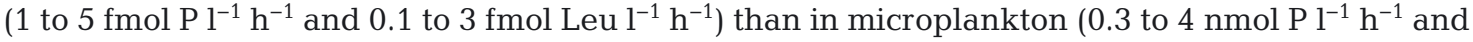
0.002 to $0.02 \mathrm{nmol} \mathrm{Leu} \mathrm{l}^{-1} \mathrm{~h}^{-1}$ ). At peak abundance, Trichodesmium contributed a major part of total ectoenzyme activity in surface waters ( $81 \%$ of APA, $64 \%$ of LAP) suggesting that the diazotrophic colonies are significant sites of net nutrient regeneration. We propose that the high rates of regeneration associated with Trichodesmium colonies may accumulate dissolved nutrients during the course of bottle incubations, which leads to isotope dilution and an underestimation of $\mathrm{P}$ and $\mathrm{N}$ uptake in radiotracer studies with these cyanobacteria.
\end{abstract}

KEY WORDS: Trichodesmium $\cdot$ Alkaline phosphatase $\cdot$ Leucine aminopeptidase $\cdot$ Regenerated production $\cdot$ Phosphorus $\cdot$ Leucine $\cdot$ Isotope dilution

\section{INTRODUCTION}

Microbial ectoenzymes are important in all aquatic systems, including oligotrophic waters, because they regenerate inorganic and organic substrates from macromolecules. Hoppe (1983) used fluorogenic analogs and demonstrated the significance of ectoenzymatic activity associated with microplankton. Since then, ectoenzyme activity associated with free- living bacteria has been shown to be important in the remineralization of particulate organic matter (POM) and dissolved organic matter (DOM) (Rath et al. 1993, Christian \& Karl 1995, Martinez et al. 1996, Christian \& Karl 1998). Intense ectoenzyme activity by bacteria attached to aggregates and marine snow can be several orders of magnitude higher than the activity associated with free bacteria (Alldredge \& Youngbluth 1985, Amy et al. 1987, Karner \& Herndl 
1992, Smith et al. 1992). Therefore, it was suggested that ectoenzyme activity by bacteria attached to particles suspended in the upper water column is an important source of regenerated nutrients to the euphotic zone (Karl et al. 1988, Simon et al. 2002).

Microbial ectoenzyme activity associated with the relatively larger sized Trichodesmium colonies, a buoyant pelagic diazotrophic cyanobacterium, can also be a hot spot of microbial activity (Nausch 1996), similar to that found in marine snow (Grossart et al. 1998). The 2 most common species at the Bermuda Atlantic Time-Series (BATS) site are Trichodesmium thiebautii and T. erythraeum (Orcutt 1999). Colonies of $T$. thiebautii can easily be separated into 2 morphologies, 'puffs' and 'tufts', but they have been found to be genetically identical (Orcutt et al. 2002). The $T$. thiebautii puffs have trichomes arranged radially to form a spherical colony, and the T. thieibautii tufts have trichomes arranged in parallel. Ectoenzymatic activity associated with colonies of Trichodesmium was reported as early as the 1970s (Yentsch et al. 1972). The multitude of procaryotic and eukaryotic organisms associated with Trichodesmium colonies (Sheridan et al. 2002) suggests that a number of organisms can be a source for ectoenzyme activities detected in association with these cyanobacteria. Since alkaline phosphatase (APA) and leucine aminopeptidase (LAP) are associated with both phytoplankton, bacteria and Trichodesmium colonies (Perry 1976, Hollibaugh \& Azam 1983, Martinez \& Azam 1993, Berges \& Falkowski 1996, Mulholland et al. 2002, Fu \& Bell 2003, Stoecker \& Gustafson 2003, Fu et al. 2005), we consider the assembly of organisms a center of ectoenzymatic regeneration of organic nutrients that may benefit all associated organisms within this consortium, including Trichodesmium itself.

Several studies have used fluorogenic substrates such as methylumbelliferyl phosphate (MUF-P) (Hoppe 1983, Ammerman 1993, Nausch 1996, Mulholland et al. 2002, Ammerman et al. 2003, Sohm \& Capone 2006, Sohm et al. 2008) or p-nitrophenylphosphate (PNPP) (Stihl et al. 2001, Fu \& Bell 2003) as a model for dissolved organic phosphate (DOP) in Trichodesmium APA measurements. Colonies of Trichodesmium have also been shown to have the ability to utilize phosphonates from the DOP pool (Dyhrman et al. 2006) and, as such, may provide regenerated nutrients to microplankton in oligotrophic systems (Dyhrman et al. 2009). Wu et al. (2000) reported that surface waters of the subtropical North Atlantic has 1 to 2 orders of magnitude lower dissolved inorganic P (DIP) levels than found in the
Pacific, suggesting that a P-depleted environment exists for the Sargasso Sea. Cross-basin comparisons between the North Pacific and North Atlantic using MUF-P substrates have also demonstrated higher enzyme rates for the North Atlantic, indicating a Plimited environment (Sohm et al. 2008). With the exception of Carlson et al. (2002), a great number of reports have suggested $\mathrm{P}$ limitation associated with bacteria (Cotner et al. 1997, Rivkin \& Anderson 1997, Caron et al. 2000, Ammerman et al. 2003, Obernosterer et al. 2003) and phytoplankton, including Trichodesmium, in the North Atlantic (Sañudo-Wilhelmy et al. 2001, Mills et al. 2004). The DOP pools at BATS are an order of magnitude higher $(80 \mathrm{nM})$ than DIP pools (5 to $10 \mathrm{nM}$; Wu et al. 2000, CavenderBares et al. 2001, Ammerman et al. 2003). Therefore, microbial APA may be an important process to regenerate inorganic $\mathrm{P}$ from DOP pools in this low nutrient environment. With the exception of Nausch (1996), who studied microbial activities on Trichodesmium colonies, little work has been done on in situ LAP activities associated with Trichodesmium colonies. An earlier study by Elardo et al. (1994) reported elevated LAP activity associated with Trichodesmium colonies and suggested that the ectoenzyme activity may be important on a microscale level, similar to elevated enzyme activities associated with marine aggregates such as marine snow (Alldredge \& Youngbluth 1985, Smith et al. 1992, Azam \& Long 2001).

In the present study, we investigated the significance of the hydrolytic activity associated with Trichodesmium, by measuring seasonal rates and kinetics of APA and LAP associated with the colonial consortium in a comparison to natural seawater. We also investigated whether the 2 morphologies of T. thiebautii, puffs and tufts, expressed significantly different rates of ectoenzyme activity. We propose that colonies of Trichodesmium at BATS are active sites of regenerated production of $\mathrm{P}$ and $\mathrm{N}$. If not accounted for, these high rates of regeneration can lead to isotope dilution and underestimation of $\mathrm{P}$ and $\mathrm{N}$ uptake in radiotracer studies.

\section{MATERIALS AND METHODS}

The BATS site $\left(31^{\circ} 50^{\prime} \mathrm{N}\right.$ and $64^{\circ} 10^{\prime} \mathrm{W}$ ) was visited between August 1992 and November 1997. Fig. 1 and Tables 1 to 5 show the times of enzyme measurements (rate comparisons, saturation kinetics), nutrient incorporation and elemental measurements performed on Trichodesmium colonies during this 
period. During each cruise, surface seawater samples were collected using a 121 Niskin water sampler attached to a CTD rosette or by using an 81 GoFlo bottle attached to a Kevlar wire. Trichodesmium colonies were collected by gently towing a plankton net at the surface ( $1 \mathrm{~m}$ diameter, $335 \mu \mathrm{m}$ mesh size) for 15 to 20 min and the collected colonies were emptied into a graduated $10 \mathrm{l}$ polypropylene bucket. Colony abundance was estimated from 300 to $400 \mathrm{ml}$ aliquot samples from the bucket and normalized to volume of filtered seawater using a General Oceanics flow meter attached to the opening of the net (Orcutt et al. 2001). Colonies of T. thiebautii were enumerated based on morphology and separated into the easily recognizable puffs (colonies with trichomes arranged radially) and tufts (trichomes arranged in parallel). Ectoenzyme activity of Trichodesmium colonies and natural seawater were compared in 2 different ways: (1) on a volumetric basis using in situ surface colony abundance and expressed as the percentage of activity contributed by Trichodesmium per total activity (Trichodesmium + seawater); and (2) using a volume concentration factor (VCF) calculated as the activity per Trichodesmium colony volume divided by the equivalent volume of seawater. The latter is a method used to compare marine snow aggregate rates with the surrounding seawater (Smith et al. 1992). In our comparisons, natural seawater was not normalized to particulate organic carbon (POC), since this would place a bias towards the large fraction of the refractive, non-living C-pool at the BATS site (Gundersen et al. 2001). Similarly, ectoenzyme rates associated with Trichodesmium were only normalized to chlorophyll pigments ( $\mathrm{chl} \mathrm{a}$ ) for comparisons to previous studies.

\section{Ectoenzyme activity associated with Trichodesmium colonies}

The APA assay measures the fluorescent end product methylumbelliferyl (MUF) that is produced when phosphate is hydrolyzed from MUF-P by the enzyme alkaline phosphatase. The APA assay was conducted in polystyrene tubes containing $10 \mathrm{ml}$ of natural seawater (microplankton) or in freshly GF/F filtered seawater with one Trichodesmium colony. The activity of APA in natural seawater was measured in comparison to the activity associated with Trichodesmium colonies. The MUF-P substrate was added and the incubation was left in the dark at ambient surface seawater temperature. The APA activity was meas- ured after 1 to $2 \mathrm{~h}$ for Trichodesmium and 3 to $4 \mathrm{~h}$ for natural seawater as described by Ammerman (1993). These relatively long incubation times are necessary due to the low biomass associated with oligotrophic seawater. The fluorescence end product was measured on a Sequoia-Turner fluorometer using filter settings of $360 \mathrm{~nm}$ narrow band excitation and 430 nm sharp cut emission (Ammerman 1993). On a routine basis, a control blank consisting of freshly (GF/F) filtered seawater was subtracted from the sample readings. No increase in background fluorescence was observed in boiled seawater with MUF-P added as substrate and pigment autofluorescence from the Trichodesmium colonies did not interfere with the assay measurements on the fluorometer. Substrate concentration for the seasonal time-series was $10 \mu \mathrm{M}$ MUF-P for the APA assay and the kinetic experiments confirmed this to be saturating.

The LAP assay measures the end product 7 -amino 4-methylcoumarin (AMC) fluorometrically when leucine is hydrolyzed from L-leucine 4-methyl-7coumarinylamide hydrochloride (Leu-MCA) by the enzyme LAP. Volumes of $10 \mathrm{ml}$ natural seawater and seawater containing 2 Trichodesmium colonies were incubated in polypropylene centrifuge tubes. The Leu-MCA substrate was added and the incubation left at ambient sea surface temperature in the dark for 2 to $4 \mathrm{~h}$ for Trichodesmium and 4 to $8 \mathrm{~h}$ for natural seawater. The fluorescence end product was measured on a Sequoia-Turner fluorometer using filter settings of $360 \mathrm{~nm}$ narrow band excitation and $430 \mathrm{~nm}$ sharp cut emission (Chróst \& Velimirov 1991). Substrate concentration for the seasonal time-series was $308 \mu \mathrm{M}$ for the LAP assay and the kinetic experiments confirmed this to be saturating.

Enzyme kinetics associated with Trichodesmium were investigated and compared to natural seawater assays of both APA and LAP. Substrate concentrations for the kinetic studies ranged from 0.1 to $50 \mu \mathrm{M}$ (APA) and 39 to $385 \mu \mathrm{M}$ (LAP) and no less than 5 substrate concentrations were used to generate each saturation curve.

\section{Phosphate and leucine incorporations}

Orthophosphate was added using a ${ }^{33} \mathrm{P}$-phosphate label (New England Nuclear Life Science Products; specific activity $4.78 \mathrm{Ci} \mathrm{mM}^{-1}$ ) and the in situ isotope dilution was calculated. Total amount of ${ }^{33} \mathrm{P}$-phosphate added to each incubation was $5 \mathrm{nM}$ and the incubation time course lasted 0.5 to $1 \mathrm{~h}$. Cells from the seawater samples were collected on $25 \mathrm{~mm}$, 
$0.2 \mu \mathrm{m}$ cellulose nitrate filters, rinsed with filtered seawater, and left to dry in separate scintillation vials. Ethyl acetate ( $1 \mathrm{ml}$, concentrated) was added to the dried filters and, following dissolution, $9 \mathrm{ml}$ of Hionic Fluor scintillation cocktail (Packard) was added to each sample. Time zero samples for seawater were filtered immediately after substrate addition and processed as an ordinary sample.

At the end of the assay, each Trichodesmium colony was transferred to a separate scintillation vial containing $250 \mu \mathrm{l}$ Milli-Q water. In order to dissolve the Trichodesmium colonies, $750 \mu$ l Soluene-350 (Packard) was added and left to dissolve, then $9 \mathrm{ml}$ of Hionic Fluor scintillation cocktail was added. After a minimum of $2 \mathrm{~d}$ and repeated vortex mixing, the samples were analyzed on a Packard Tricarb Analyzer using the external channel ratio method. In order to correct for ${ }^{33} \mathrm{P}$-phosphate adsorption to the colonies, time zero samples were made by dipping and immediately removing Trichodesmium colonies from the incubation solution.

Leucine incorporation was measured using L-[4, 5${ }^{3} \mathrm{H}$ ] leucine $\left({ }^{3} \mathrm{H}\right.$-leucine, New England Nuclear Life Science Products) at a final concentration of $21 \mathrm{nM}$ (specific activity 7 to $8 \mathrm{Ci} \mathrm{mM}^{-1}$ ). In order to obtain total incorporation of ${ }^{3} \mathrm{H}$-leucine, the samples were not extracted in trichloroacetic acid (TCA), but otherwise followed the method described by Kirchman et al. $(1985,1986)$. Cells from seawater samples were collected on $25 \mathrm{~mm}, 0.2 \mu \mathrm{m}$ cellulose nitrate filters, rinsed with filtered seawater and put in a scintillation vial to dry. Ethyl acetate (1 ml, concentrated) was added to the dried samples and left to dissolve overnight. Hionic Fluor scintillation cocktail $(9 \mathrm{ml})$ was added to each sample before analysis on a Packard Tricarb Analyzer.

Leucine incorporation by Trichodesmium was measured with the same final substrate concentration as for seawater and the colonies were collected, processed and time zero corrected as described in the ${ }^{33} \mathrm{P}$-phosphate incubation.

\section{Elemental cell content and $\mathrm{chl} \boldsymbol{a}$ in colonies of Trichodesmium}

Net-tow collected colonies were analyzed for cellular organic carbon (C), nitrogen (N) and phosphorus (P) on selected cruises to the BATS site between August 1992 and November 1997. During the abundance estimation of a net-tow, all enumerated colony morphologies were routinely placed in beakers containing GF/F-filtered seawater. Colonies for $\mathrm{C}$ and $\mathrm{N}$ analysis ( 2 to 5 per sample) were transferred to precombusted $7 \mathrm{~mm}$ GF/F filters using a $1 \mu \mathrm{l}$ inoculation loop. The samples were dried at $60^{\circ} \mathrm{C}$ overnight and fumigated in $\mathrm{HCl}$. The re-dried filters were analyzed on a Control Equipment Corporation 240-XA Elemental Analyzer and the results corrected with empty filter blanks. Colonies for cellular P analysis (3 to 15 per sample) were either placed on a precombusted GF/C filter or left in $250 \mu \mathrm{l}$ of Milli-Q water in an acid-cleaned scintillation vial. Before the samples were dried at $95^{\circ} \mathrm{C}, 1 \mathrm{ml}$ of $0.017 \mathrm{M}$ magnesium sulfate was added, combusted and finally, hydrolyzed in hydrochloric acid (Solorzano \& Sharp 1980). In 1992, the hydrolyzed phosphate was analyzed manually according to Strickland \& Parsons (1972). Thereafter, phosphate analysis was carried out using a Technicon Auto Analyzer II optimized for low-level detection of the phospho-molybdenum blue complex (Gordon et al. 1993). The results were corrected with GF/F filter or Milli-Q water blanks as appropriate. Colonies were collected for chl a analysis in August, October, November 1997 and in January 1998. Each colony was placed on a $25 \mathrm{~mm} \mathrm{GF/F}$ filter and stored separate in liquid nitrogen. The samples were extracted in $90 \%$ acetone at $-20^{\circ} \mathrm{C}$ and analyzed on a Turner Design 110 fluorometer according to Strickland \& Parsons (1972).

\section{RESULTS}

\section{Ectoenzyme activity in seawater and associated with Trichodesmium colonies}

Overall, the rate of APA associated with Trichodesmium colonies was not higher for tufts than for puffs (Table 1). Time-series measurements of APA in surface seawater ranged from 0.8 to $4 \mathrm{nmol}^{-1} \mathrm{~h}^{-1}$ and showed higher rates in spring and summer (Fig. 1A). Rates of APA associated with Trichodesmium puffs in surface waters (Fig. 1B) were an average of $28 \mathrm{nmol}_{\text {colony }}{ }^{-1} \mathrm{~h}^{-1}$ for puffs (range 4 to 66) and, although not unequivocally, showed a similar seasonal trend to seawater microplankton. The halfsaturation constant $\left(K_{\mathrm{m}}\right)$ for APA associated with Trichodesmium colonies was higher than seawater APA (Table 2). Surface seawater APA showed a narrow range in $K_{\mathrm{m}}(0.1$ to $1 \mu \mathrm{M})$ compared to Trichodesmium (puffs, 2 to $29 \mu \mathrm{M}$; tufts, 2 to $6 \mu \mathrm{M}$ ).

The LAP activity associated with seawater ranged from 0.6 to $17 \mathrm{nmol}^{-1} \mathrm{~h}^{-1}$ and showed a strong seasonal pattern with higher rates in spring and late fall (Fig. 1C). Average LAP activity of Trichodesmium 
Table 1. Comparison of alkaline phosphatase (APA) and leucine aminopeptidase (LAP) rates in Trichodesmium puff and tufts colonies at different substrate concentrations. Standard errors (SE) and the number of replicate incubation tubes (n) are shown for all incubations. A Student's $t$-test of difference between 2 sample means was tested for significance at the $95 \%$ confidence level $\left({ }^{* *} \mathrm{p}<0.05\right)$ using degrees of freedom $\left(\mathrm{df}=\mathrm{n}_{1}+\mathrm{n}_{2}-2\right)$ for unequal sample size $\mathrm{n}<30$ (Sokal \& Rohlf 1969)

\begin{tabular}{|c|c|c|c|c|c|c|c|c|c|c|}
\hline & \multirow{2}{*}{$\begin{array}{l}\text { Substrate } \\
\qquad(\mu \mathrm{M})\end{array}$} & \multicolumn{6}{|c|}{ Enzyme activity (nmol colony ${ }^{-1} \mathrm{~h}^{-1}$ ) } & \multicolumn{3}{|c|}{ Significance (Tuft > Puff) } \\
\hline & & Puff & SE & $\mathrm{n}$ & Tuft & SE & $\mathrm{n}$ & $\mathrm{df}$ & $t$ & $\mathrm{p}$ \\
\hline \multicolumn{11}{|l|}{ APA } \\
\hline Aug 29, 1992 & 0.1 & 1.01 & 0.40 & 6 & 1.99 & 0.92 & 12 & 16 & 4.931 & $<0.05^{* *}$ \\
\hline Nov 25, 1992 & 0.1 & 0.59 & 0.37 & 4 & 0.96 & 0.37 & 4 & 6 & 1.414 & $>0.4$ \\
\hline Apr 21, 1994 & 20 & 20.81 & 16.68 & 2 & 134.35 & 66.85 & 2 & 2 & 2.330 & $>0.2$ \\
\hline Mar 15, 1996 & 10 & 0.85 & 0.17 & 3 & 1.34 & 0.47 & 3 & 4 & 1.698 & $>0.2$ \\
\hline Jul 9, 1996 & 10 & 0.14 & 0.13 & 3 & 1.47 & 0.71 & 3 & 4 & 3.191 & $<0.05^{* *}$ \\
\hline Nov 6, 1996 & 10 & 0.32 & 0.16 & 3 & 1.61 & 0.99 & 3 & 4 & 2.228 & $>0.1$ \\
\hline \multicolumn{11}{|l|}{ LAP } \\
\hline Dec 9, 1993 & 154 & 30.95 & 9.27 & 2 & 52.75 & 0.98 & 2 & 2 & 3.307 & $>0.05$ \\
\hline Jan 24, 1994 & 308 & 206.94 & 24.21 & 3 & 240.32 & 99.22 & 3 & 4 & 0.566 & $>0.5$ \\
\hline Apr 5, 1994 & 308 & 205.32 & 68.01 & 3 & 273.95 & 82.50 & 3 & 4 & 1.112 & $>0.4$ \\
\hline Jul 25, 1995 & 200 & 79.97 & 21.97 & 2 & 180.30 & 85.21 & 2 & 4 & 1.591 & $>0.2$ \\
\hline
\end{tabular}
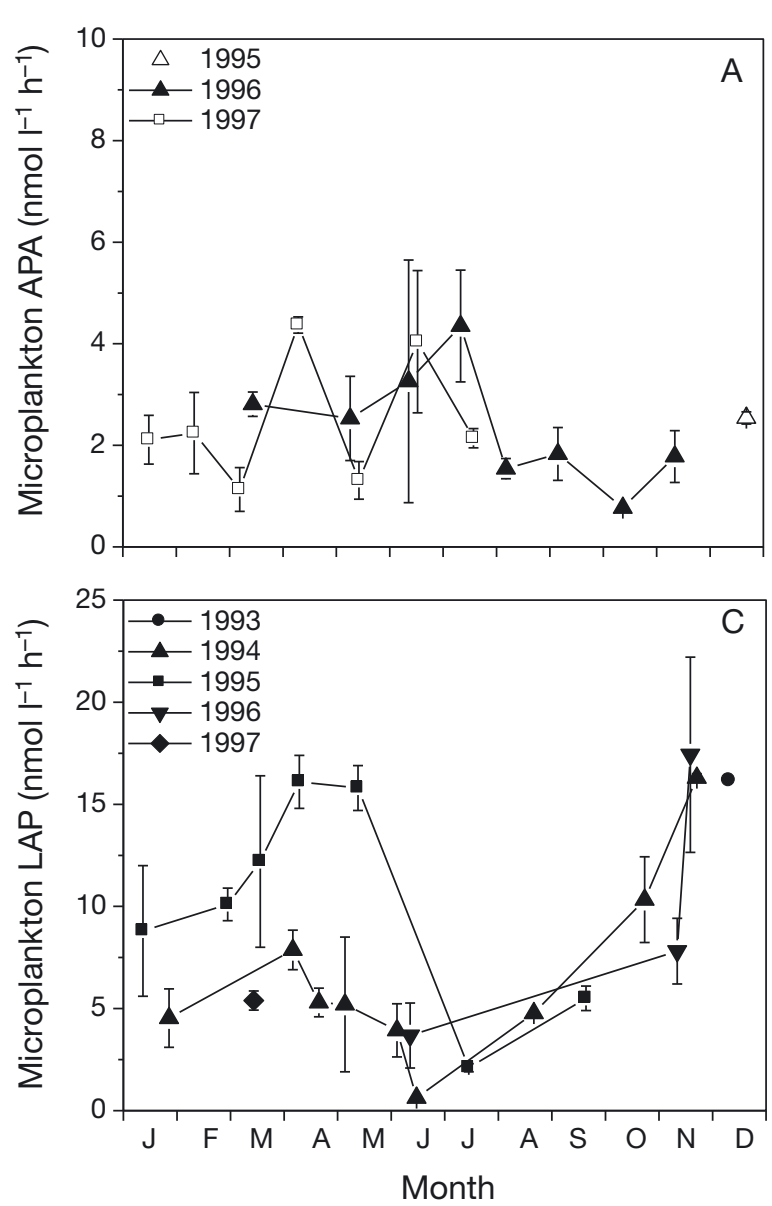
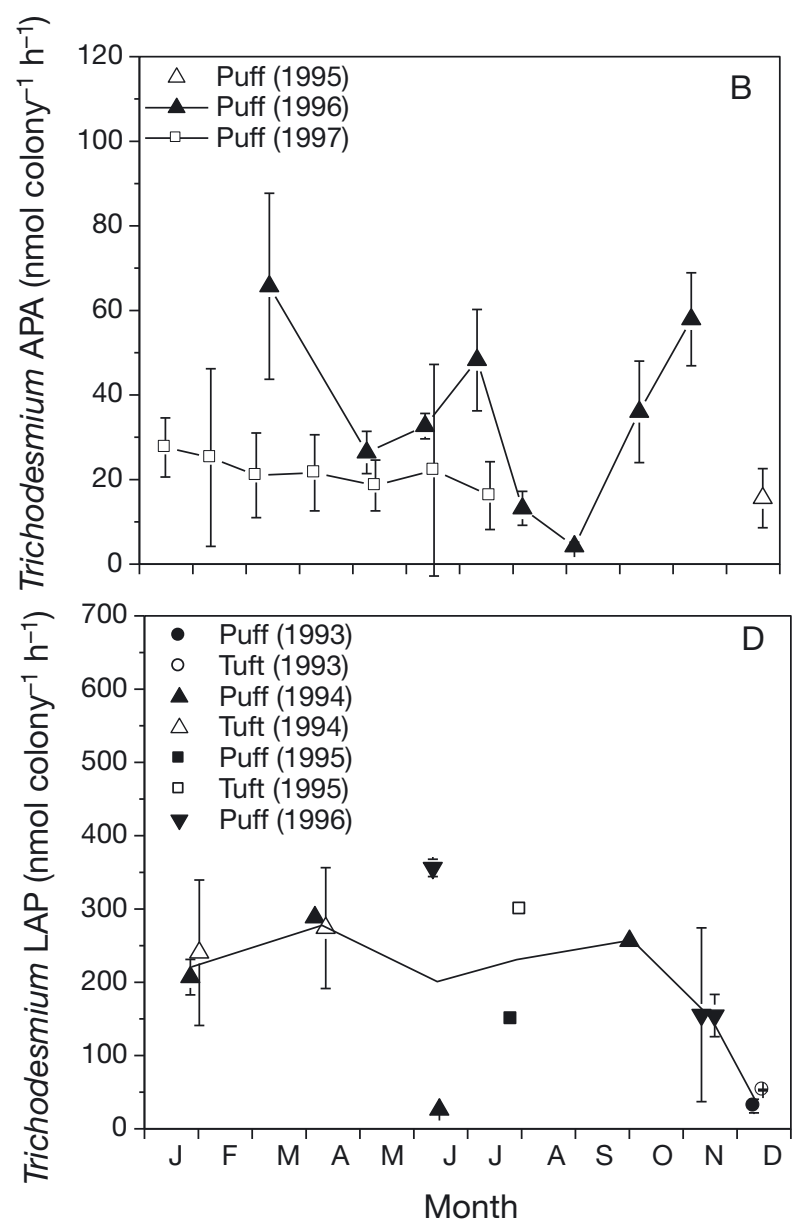

Fig. 1. Ectoenzyme activities measured at the Bermuda Atlantic Time-Series (BATS) site as a function of time within one generic year. Measurements of alkaline phosphatase (APA) were made (A) on microplankton and (B) in association with Trichodesmium colonies between 1995 and 1997. Measurements of leucine aminopeptidase (LAP) were made (C) on microplankton and (D) in association with Trichodesmium colonies between 1993 and 1997. Number of data points $>7$ within a year have

lines connecting the symbols. The line in D shows calculated combined monthly averages of LAP in puffs and tufts 
Table 2. APA and LAP kinetics measured in surface seawater and associated with Trichodesmium colonies collected in the vicinity and at the BATS site between August 1992 and July 1995. The half-saturation constant $\left(K_{\mathrm{m}}\right)$ and maximum rate of enzyme activity ( $V_{\max }$ ) were calculated for seawater $\left(\mathrm{nmol} \mathrm{l} \mathrm{l}^{-1} \mathrm{~h}^{-1}\right)$ and cyanobacteria (nmol colony ${ }^{-1} \mathrm{~h}^{-1}$ ) using a Model I linear regression of a Lineweaver-Burk plot. A log-transformed geometric mean and range was generated from the number of saturation plots (n). Substrate concentrations ranged between 0.1-50 $\mu \mathrm{M}$ (APA) and 39$385 \mu \mathrm{M}$ (LAP)

\begin{tabular}{|lccrcc|}
\hline & \multicolumn{2}{c}{$K_{\mathrm{m}}(\mu \mathrm{M})$} & \multicolumn{2}{c}{$V_{\text {max }}$} & $\mathrm{n}$ \\
& Mean & Range & Mean & Range & \\
\hline APA & & & & & \\
Seawater & 0.2 & $0.1-1$ & 3 & $1-29$ & 11 \\
Puffs & 8 & $2-29$ & 46 & $15-104$ & 8 \\
Tufts & 4 & $2-6$ & 145 & $91-254$ & 4 \\
LAP & & & & & \\
Seawater & 171 & $87-408$ & 14 & $1-124$ & 7 \\
Puffs & 156 & $45-594$ & 147 & $54-377$ & 7 \\
Tufts & 121 & $68-175$ & 382 & $217-578$ & 5 \\
\hline
\end{tabular}

colonies was $201 \mathrm{nmol}$ colony ${ }^{-1} \mathrm{~h}^{-1}$ for puffs (range 26 to 389) and $216 \mathrm{nmol}$ colony ${ }^{-1} \mathrm{~h}^{-1}$ for tufts (range 53 to 299). The LAP activity was similar for both puff and tuft colonies and there was no apparent seasonal pattern (Fig. 1D). The $K_{\mathrm{m}}$ for LAP activity associated with Trichodesmium colonies and seawater was similar (Table 2) while the average calculated maximum rate of enzyme activity $\left(V_{\max }\right)$ was much higher in Trichodesmium tufts.

The contribution of Trichodesmium ectoenzyme activity towards total APA and LAP (compared with seawater on a per volume basis) varied with observed colony abundance (Table 3). At peak colony abundance, Trichodesmium constituted more than $3 / 4$ of total APA and approximately $2 / 3$ of total LAP. By using the volume concentration factor to compare marine aggregates with seawater (Smith et al. 1992), Trichodesmium APA and LAP activities were 6 to 7 orders of magnitude higher than seawater ectoenzyme activities (Table 3).

\section{Phosphate and leucine incorporation by Trichodesmium}

The incorporation of $\mathrm{P}$ associated with Trichodesmium colonies and seawater plankton ranged from 0.3 to 0.7 pmol colony ${ }^{-1} \mathrm{~h}^{-1}$ and 0.3 to $4 \mathrm{pmol} \mathrm{l}^{-1}$ $\mathrm{h}^{-1}$, respectively (Table 4 ). The calculated P incorporation rate by Trichodesmium, normalized to volume of seawater using in situ colony abundance distribu- tion, was 5 to 6 orders of magnitude lower than natural seawater plankton (Table 4 ).

The incorporation of ${ }^{3} \mathrm{H}$-leucine associated with Trichodesmium colonies and seawater plankton ranged from 0.02 to 0.2 pmol colony ${ }^{-1} \mathrm{~h}^{-1}$ and 0.002 to 0.02 pmol $^{-1} \mathrm{~h}^{-1}$, respectively (Table 4). The ${ }^{3} \mathrm{H}$ leucine incorporation rates associated with the colonies, normalized to volume of seawater, was 4 to 6 orders of magnitude lower than the incorporation rate measured in seawater plankton (Table 4).

\section{Elemental $\mathrm{C}, \mathrm{N}$ and $\mathbf{P}$ cell content and chl $a$ in Trichodesmium}

The elemental cell content in puffs ranged between 5-12 $\mu \mathrm{g}$ C, $0.9-2 \mu \mathrm{g} \mathrm{N}$ and 0.03-0.2 $\mu \mathrm{g} \mathrm{P}$ colony $^{-1}$, whereas the tufts ranged between $6-19 \mu \mathrm{g}$ C, 1-4 $\mu \mathrm{g} \mathrm{N}$ and 0.04-0.06 $\mu \mathrm{g} \mathrm{P}$ (Table 5). The elemental molar $\mathrm{C}: \mathrm{N}$ ratio ranged between $4-7$ and the average was similar to the Redfield stoichiometry of 6.6 (Table 5). The molar C:P ratios of Trichodesmium colonies were higher than the Redfield stoichiometry of 106 at all times at the BATS site during this study (Table 5) and most apparent in tuft colonies. Average pigment content was $48 \mathrm{ng} \mathrm{chl}$ a colony $^{-1}$ (range 35 to 62 ).

\section{DISCUSSION}

\section{Ectoenzyme activity generated by the Trichodesmium consortium}

Microbial activity found in organic aggregations such as marine snow (Alldredge \& Youngbluth 1985, Smith et al. 1992, Azam \& Long 2001) can be a major biological process in oceanic environments (Azam 1998). Similarly, Nausch (1996) investigated microbial activities associated with Trichodesmium colonies and suggested that bacteria play an active role in the degradation of the colonies. Paerl et al. (1989), however, suggested that bacteria associated with Trichodesmium colonies are symbiotic or mutualistic in nature, and a great number of other studies have shown that APA and LAP can be associated with marine phytoplankton, bacteria and cyanobacteria (Perry 1976, Hollibaugh \& Azam 1983, Martinez \& Azam 1993, Berges \& Falkowski 1996, Mulholland et al. 2002, Fu \& Bell 2003, Stoecker \& Gustafson 2003, $\mathrm{Fu}$ et al. 2005). Colonies of Trichodesmium harbor an assortment of both prokaryotic and eukaryotic organisms (Sheridan et al. 2002) and each colony 
Table 3. APA and LAP activities measured in surface seawater and associated with Trichodesmium colonies collected in the vicinity and at the BATS site. Seawater plankton (Seawater) enzyme activities were compared to Trichodesmium per liter (Abundance $\times$ Trichodesmium) using known estimates of colony abundance, and the fraction activity contributed by Trichodesmium (\% Tricho) was calculated as the percentage of total enzyme activity measured (Trichodemsium + Seawater). A second set of comparisons were made similar to the Smith et al. (1992) study; the volume concentration factor (VCF) was calculated as the fraction of activity in the volume of a Trichodesmium colony, per activity in the equivalent volume of seawater. For the VCF comparison, we assumed an average diameter of $1250 \mu \mathrm{m}$ of the spherical Trichodesmium puff colonies (Carpenter \& McCarthy 1975, Post et al. 2002) and calculated an average volume of $1 \times 10^{9} \mu^{3}$ per colony

\begin{tabular}{|lrcrrr|}
\hline Date & $\begin{array}{c}\text { Abundance } \\
\left(\text { colony } \mathrm{m}^{-3}\right)\end{array}$ & $\begin{array}{c}\text { Trichodesmium } \\
\left(\mathrm{nmol} \mathrm{colony}^{-1} \mathrm{~h}^{-1}\right)\end{array}$ & $\begin{array}{c}\text { Seawater } \\
\left(\mathrm{nmol}^{-1} \mathrm{~h}^{-1}\right)\end{array}$ & $\begin{array}{c}\% \\
\text { Tricho }\end{array}$ & $\begin{array}{c}\text { VCF } \\
\left(\times 10^{7}\right)\end{array}$ \\
\hline APA & & & & & \\
Dec 1995 & 4.8 & 15.6 & 2.5 & 2.9 & 0.6 \\
Mar 1996 & 0.8 & 65.7 & 2.8 & 1.9 & 2.3 \\
May 1996 & 2.8 & 26.4 & 2.5 & 2.8 & 1.0 \\
Jun 1996 & 5.0 & 32.6 & 3.3 & 4.8 & 1.0 \\
Jul 1996 & 15.6 & 48.2 & 4.4 & 14.7 & 1.1 \\
Aug 1996 & 30.1 & 13.2 & 1.5 & 20.5 & 0.8 \\
Sep 1996 & 18.5 & 4.2 & 1.8 & 4.1 & 0.2 \\
Oct 1996 & 89.2 & 36.0 & 0.8 & 80.7 & 4.6 \\
Nov 1996 & 16.4 & 57.9 & 1.8 & 34.8 & 3.2 \\
Jan 1997 & 1.0 & 27.6 & 2.1 & 1.3 & 1.3 \\
Feb 1997 & 2.4 & 25.2 & 2.2 & 2.6 & 1.1 \\
Mar 1997 & 2.3 & 21.0 & 1.1 & 4.0 & 1.8 \\
Apr 1997 & 0.2 & 21.6 & 4.4 & 0.1 & 0.5 \\
May 1997 & 0.2 & 18.6 & 1.3 & 0.3 & 1.4 \\
Jun 1997 & 1.5 & 22.2 & 4.0 & 0.8 & 0.5 \\
Jul 1997 & 13.9 & 16.2 & 2.1 & 9.5 & 0.7 \\
LAP & & & & & \\
Dec 1993 & 2.5 & 31.0 & 16.2 & 0.5 & 0.2 \\
Jan 1994 & 1.3 & 206.9 & 4.5 & 5.6 & 4.5 \\
Apr 1994 & 0.5 & 288.6 & 7.9 & 1.9 & 3.6 \\
Jul 1994 & 10.7 & 26.2 & 0.6 & 30.7 & 4.1 \\
Jun 1996 & 5.0 & 356.1 & 3.7 & 32.6 & 9.5 \\
Oct 1996 & 89.2 & 155.6 & 64.0 & 1.9 \\
Nov 1996 & 16.4 & 154.6 & & 12.7 & 0.9 \\
& & & & & \\
\hline
\end{tabular}

should be viewed as a consortium of heterotrophic and autotrophic processes that are difficult to separate. Therefore, Trichodesmium should be included as one of the many organisms that may produce ectoenzymes and we cannot assign APA and LAP rates to certain groups within the consortium of a colony as has been done in other studies. Since Trichodesmium puffs appear to have more epiphytic organisms associated with the colonies (Borstad \& Borstad 1977, Sheridan et al. 2002), we had anticipated higher ectoenzyme rates associated with this morphology. In our study, however, the difference in APA associated with puff and tuft colonies of Trichodesmium was most frequently insignificant (Table 1).

\section{Seasonal rates of APA and LAP}

In oligotrophic waters, DOM generated from autotrophic phytoplankton can be a major source of substrate for enzyme nutrient regeneration (Azam 1998). Timeseries data from the Sargasso Sea gyre show a short-lived bloom of phytoplankton in spring (Lohrenz et al. 1992) that generate a relatively low but significant amount of DOM during this period of time (Carlson et al. 1994, Hansell \& Carlson 2001). Since all enzyme activities are substrate resource driven, we would expect higher rates of ectoenzymatic activity during times of high photosynthesis and release of DOM. Therefore, the higher rates of APA and LAP associated with seawater microplankton in spring (Fig. 1) were expected. Peaks in APA could be found well into summer (Fig. 1A) and this was well beyond the release of DOM associated with primary productivity in April-May at BATS (Carlson et al. 1994, Hansell \& Carlson 2001). However, the surface seawater APA peaks in summer coincide with peak abundances in free trichomes and colonies of Trichodesmium (Orcutt et al. 2001), which may provide a source of DOM for the surrounding seawater microplankton. McCarthy \& Carpenter (1979) found high APA rates $(0.2$ to $0.3 \mu \mathrm{mol} P$ $\mu^{-1}$ chl a $\mathrm{h}^{-1}$ ) associated with Trichodesmium colonies using relatively low $(0.05 \mu \mathrm{M})$ substrate concentrations. By using substrate concentrations equal to $0.1 \mu \mathrm{M}$, the APA rates associated with Trichodesmium in this study (1.1 to $1.52 \mu \mathrm{mol} \mathrm{P} \mu^{-1} \mathrm{chl} \mathrm{a}$ $\mathrm{h}^{-1}$ ) were similar to the McCarthy \& Carpenter (1979) study (Table 6). More recently, Sohm \& Capone (2006) used similar substrate concentrations $(0.1 \mu \mathrm{M})$ and reported APA rates associated with Trichodesmium colonies from the western Sargasso Sea (0.003 to 0.01

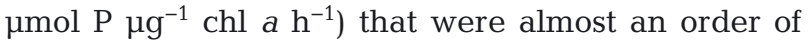
magnitude lower than the earlier reports from the same region (Table 6). The $K_{\mathrm{m}}$ of Trichodesmium APA was higher than seawater (Table 2) and this is indicative of an enzyme adapted to high concentrations of 
Table 4. Rates of P- and Leu-incorporation associated with Trichodesmium puff colonies and in seawater plankton collected at the BATS site. Seawater plankton incorporation rates (Seawater) were compared to Trichodesmium per liter (Abund. $\times$ Activity) using known estimates of colony abundance. Note the different units in the volumetric rates. ND: no data

\begin{tabular}{|c|c|c|c|c|}
\hline & \multirow[b]{2}{*}{$\begin{array}{l}\text { Abundance } \\
\left(\text { colony } \mathrm{m}^{-3} \text { ) }\right.\end{array}$} & \multicolumn{2}{|c|}{ _ Trichodesmium } & \multirow{2}{*}{$\begin{array}{c}\text { Seawater } \\
\left(\mathrm{nmol} \mathrm{l}^{-1} \mathrm{~h}^{-1}\right)\end{array}$} \\
\hline & & $\begin{array}{c}\text { Activity } \\
\left(\mathrm{pmol} \text { colony } \mathrm{y}^{-1} \mathrm{~h}^{-1}\right)\end{array}$ & $\begin{array}{l}\text { Abund. } \times \text { Activity } \\
\left(\mathrm{fmol} \mathrm{l}^{-1} \mathrm{~h}^{-1}\right)\end{array}$ & \\
\hline \multicolumn{5}{|c|}{ P-incorporation } \\
\hline \multicolumn{5}{|c|}{1996} \\
\hline Nov 6 & 16.4 & 0.27 & 4.5 & 0.78 \\
\hline Nov 14 & 8.3 & 0.34 & 2.8 & 0.26 \\
\hline \multicolumn{5}{|l|}{1997} \\
\hline Feb 7 & 2.4 & 0.50 & 1.2 & 0.50 \\
\hline Mar 5 & 2.3 & 0.67 & 1.5 & 3.96 \\
\hline \multicolumn{5}{|c|}{ Leu-incorporation } \\
\hline \multicolumn{5}{|c|}{1994} \\
\hline Jul 21 & 1.0 & 0.13 & 0.1 & 0.002 \\
\hline Aug 1 & 0.7 & 0.22 & 0.2 & ND \\
\hline \multicolumn{5}{|l|}{1996} \\
\hline Apr 9 & 5.0 & 0.10 & 0.5 & 0.009 \\
\hline May 7 & 11.8 & 0.10 & 1.2 & 0.013 \\
\hline Jun 11 & 25.0 & 0.02 & 0.5 & 0.021 \\
\hline Aug 6 & 26.4 & 0.13 & 3.4 & 0.015 \\
\hline Nov 6 & 16.4 & 0.10 & 1.6 & 0.010 \\
\hline
\end{tabular}

Table 5. Elemental carbon (C), nitrogen (N) and phosphorus (P) in Trichodesmium colonies collected in surface waters at BATS. Elemental content $\left(\mu \mathrm{g} \mathrm{colony}^{-1}\right.$ ) and the molar $\mathrm{C}: \mathrm{N}: \mathrm{P}$ ratios of the colonies are arranged in a composite year. Each SE was calculated from the analyzed means of samples (n) each containing 3 colonies. ND: no data

\begin{tabular}{|lrrrrrrrrrrr|}
\hline Date & $\mathrm{C}$ & $\mathrm{SE}$ & $\mathrm{n}$ & $\mathrm{N}$ & $\mathrm{SE}$ & $\mathrm{n}$ & $\mathrm{P}$ & $\mathrm{SE}$ & $\mathrm{n}$ & $\mathrm{C}: \mathrm{N}$ & $\mathrm{C}: \mathrm{P}$ \\
\hline Puffs & & & & & & & & & & & \\
Mar 1993 & 7.4 & 0.3 & 3 & 1.5 & 0.2 & 3 & 0.071 & 0.020 & 6 & 6 & 269 \\
Apr 1994 & 11.6 & 4.5 & 9 & 2.2 & 0.8 & 9 & 0.171 & 0.075 & 5 & 6 & 175 \\
Jun 1997 & 7.3 & 0.7 & 3 & 1.9 & 0.1 & 3 & 0.074 & 0.013 & 3 & 4 & 255 \\
Jul 1997 & 4.8 & 2.5 & 12 & 0.9 & 0.5 & 12 & 0.076 & 0.021 & 3 & 6 & 163 \\
Aug 1992 & 6.5 & 2.4 & 23 & 1.2 & 0.5 & 23 & $\mathrm{ND}$ & & & 6 & $\mathrm{ND}$ \\
Nov 1997 & 9.3 & 2.8 & 28 & 1.8 & 0.5 & 28 & 0.033 & 0.010 & 3 & 6 & 728 \\
Tufts & & & & & & & & & & & \\
Mar 1993 & 6.3 & 5.0 & 2 & 1.1 & 1.0 & 2 & $\mathrm{ND}$ & & & 7 & ND \\
Jun 1997 & 19.0 & 3.9 & 4 & 3.6 & 0.9 & 4 & 0.047 & 0.012 & 3 & 6 & 1044 \\
Jul 1997 & 19.4 & 2.5 & 3 & 4.0 & 0.5 & 3 & 0.056 & 0.008 & 3 & 6 & 895 \\
Aug 1992 & 9.6 & 4.1 & 20 & 1.7 & 0.8 & 20 & 0.049 & 0.004 & $2^{\mathrm{a}}$ & 7 & 506 \\
Nov 1997 & 8.6 & 4.0 & 16 & 1.4 & 0.9 & 16 & 0.038 & 0.001 & 2 & 7 & 585 \\
a Average of colonies collected from surface waters and at 100 m depth \\
\hline
\end{tabular}

organic P associated with the cyanobacterial colonies. Our results suggest that Trichodesmium colonies are able and capable of rapidly hydrolyzing high concentrations of DOP. There is only one other in situ study of LAP associated with Trichodesmium colonies (Table 6) and the substrate concentration used in that study was more than 3 orders of magnitude lower than the range in our study. Although the measured rates of LAP in this study show a wider range (Table 6), the high range of substrate concentrations, in both Trichodesmium and seawater, may suggest that LAP is capable of responding to high concentrations of dissolved organic nitrogen (DON).

\section{Substrate saturation and multiple enzyme kinetics}

Increasing substrate concentrations usually yield higher rates of a single ectoenzyme activity until a saturation level is reached. Recent genetic studies, however, have established that Trichodesmium contain 2 APAs (phoX and phoA) Orchard et al. 2009) and 3 different APAs (phoX, phoD and phoA) have been found associated with marine bacteria (Luo et al. 2009, Sebastian \& Ammerman 2009). Similarly, the Leu-MCA substrate used for LAP measurements is regarded as a model substrate for a number of different proteases (Berges \& Falkowski 1996, Obayashi \& Suzuki 2005) and, hence, a multitude of different saturation kinetics can be expected depending on the predominant ectoenzymes. Martinez et al. (1996) reported shifts in the enzyme kinetics of ectoenzymes and suggested they were caused by changes in species composition within the microplankton community. Also, Elardo et al. (1994) suggested that different ectoenzymes may become engaged when extreme ranges in concentrations of the APA and LAP substrates were applied in assays. In poorly described pools of ectoenzymes, such as APA and LAP in seawater or associated with colonies of Trichodesmium, a multitude of similar enzymes with dramatically different enzyme kinetics may coexist. Therefore, these in situ assays may not be as straight forward to interpret as the ones observed in monoculture experiments.

Berges \& Falkowski (1996) and Martinez et al. (1996) found LAP in cyanobacteria with a compara- 
ble but wider range of substrate saturations (115 to $879 \mu \mathrm{M}$ ) to this study (Table 2), but this is at the higher end of what has been reported from coastal estuaries in central Europe (Somville \& Billen 1983) and from the central Pacific Ocean (Christian \& Karl 1998). Only APA associated with colonies of Trichodesmium, however, exhibited higher $K_{\mathrm{m}}$ when compared to seawater (Table 2) and, hence, the colonies appeared to be only adjusted to higher concentrations of DOP. Karl et al. (1992) found a 3-fold enrichment of DON and more than 27 times higher concentrations of ammonium in water samples collected during a Trichodesmium bloom at Stn ALOHA off Hawaii. Therefore, the high rates of LAP found in this study, the amino acid oxidation reported by Mulholland et al. (1998) and reports of the release of recently fixed nitrogen (Glibert \& Bronk 1994, Capone et al. 1994), suggest that Trichodesmium colonies can be a point source of DON in the sea. The summary of current literature (Table 6) also shows a general agreement that higher substrate concentrations yield higher rates of APA and LAP. We propose that the high rates of APA and LAP associated with colonies of Trichodesmium at high substrate concentrations are an adaptive response to the high concentrations of dissolved organic substrates produced by the cyanobacterial consortium.

\section{Colonies of Trichodesmium as a source of organic and inorganic nutrients}

The molar C:N ratio of the Trichodesmium colonies in this study was similar to the Redfield stoichiometry, but the cellular quota for P in the diazotrophs was low (Table 5). Elevated C:P ratios in Trichodemium colonies have also been found in a number of other studies (Mague et al. 1977, Karl et al. 1995, Letelier \& Karl 1996, 1998, Sañudo-Wilhelmy et al. 2001, 2004, Mulholland et al. 2002, Fu et al. 2005,

Table 6. Summary of ectoenzyme in situ measurements associated with colonies of Trichodesmium. Averages (and range) were calculated from a number of single estimates (n) reported from each site. MFP = 3-0-methylfluorescein phosphate; MUF$\mathrm{P}=4$-methylumbelliferyl phosphate; PNPP = p-nitrophenylphosphate; Leu-MCA = L-leucine 4-methyl-7-coumarinylamide hydrochloride

\begin{tabular}{|c|c|c|c|c|c|c|}
\hline Sampling site & Substrate & {$[\mu \mathrm{M}]$} & \multicolumn{2}{|c|}{$\mu \mathrm{mol} \mu \mathrm{g}^{-1} \mathrm{chl} \mathrm{ah}^{-1}$} & $\mathrm{n}$ & Source \\
\hline \multicolumn{7}{|l|}{ APA } \\
\hline North Atlantic (Sargasso Sea) & MFP & 0.05 & 0.24 & $0.17-0.30$ & 2 & McCarthy \& Carpenter (1979) \\
\hline NE Caribbean & MUF-P & 0.05 & 0.14 & $0.03-0.35^{\mathrm{a}}$ & 20 & Nausch (1996) \\
\hline Gulf of Aqaba (coastal) & PNPP & 400 & 0.23 & $0.15-0.36$ & 4 & Stihl et al. (2001) \\
\hline Gulf of Aqaba (open waters) & PNPP & 400 & 12.2 & $3.1-31.6$ & 4 & Stihl et al. (2001) \\
\hline NE Caribbean & MUF-P & 0.1 & 0.11 & $0.03-0.24$ & 9 & Mulholland et al. (2002) \\
\hline Off Northern Australia & MUF-P & 0.1 & 0.004 & $0.001-0.010$ & 14 & Mulholland et al. (2002) \\
\hline Great Barrier Reef (culture) & PNPP & 417 & 0.002 & $0.001-0.007^{\mathrm{b}}$ & 5 & Fu \& Bell (2003) \\
\hline Western Atlantic (Sargasso Sea) & MUF-P & 0.1 & 0.006 & $0.002-0.010$ & 3 & Sohm \& Capone (2006) \\
\hline Atlantic (Amazon Plume) & MUF-P & 0.1 & 0.016 & $0.005-0.070^{\mathrm{c}}$ & 8 & Sohm et al. (2008) \\
\hline Pacific (SW off Hawaii) & MUF-P & 0.2 & 0.011 & $0.001-0.012^{\mathrm{c}}$ & 6 & Sohm et al. (2008) \\
\hline Sargasso Sea (BATS) & MUF-P & 0.1 & 0.05 & $0.01-0.10^{\mathrm{d}}$ & 7 & Present study \\
\hline Sargasso Sea (BATS) & MUF-P & 1 & 0.13 & $0.08-0.17^{d}$ & 6 & Present study \\
\hline Sargasso Sea (BATS) & MUF-P & 5 & 0.41 & $0.31-0.65^{\mathrm{d}}$ & 3 & Present study \\
\hline Sargasso Sea (BATS) & MUF-P & 10 & 0.56 & $0.20-2.76^{\mathrm{d}}$ & 10 & Present study \\
\hline Sargasso Sea (BATS) & MUF-P & 20 & 1.09 & $0.38-4.13^{\mathrm{d}}$ & 5 & Present study \\
\hline Sargasso Sea (BATS) & MUF-P & 50 & 1.52 & $0.57-4.92^{\mathrm{d}}$ & 6 & Present study \\
\hline \multicolumn{7}{|l|}{ LAP } \\
\hline NE Caribbean & Leu-MCA & 0.05 & 0.038 & $0.006-0.12^{\mathrm{a}}$ & 20 & Nausch (1996) \\
\hline Sargasso Sea (BATS) & Leu-MCA & 40 & 0.26 & $0.21-0.31^{\mathrm{d}}$ & 2 & Present study \\
\hline Sargasso Sea (BATS) & Leu-MCA & 77 & 1.46 & $0.21-3.05^{\mathrm{d}}$ & 6 & Present study \\
\hline Sargasso Sea (BATS) & Leu-MCA & 154 & 1.65 & $0.65-3.8^{\mathrm{d}}$ & 7 & Present study \\
\hline Sargasso Sea (BATS) & Leu-MCA & 308 & 4.90 & $3.22-8.10^{\mathrm{d}}$ & 8 & Present study \\
\hline Sargasso Sea (BATS) & Leu-MCA & 385 & 5.06 & $3.20-8.01^{\mathrm{d}}$ & 2 & Present study \\
\hline \multicolumn{7}{|c|}{ 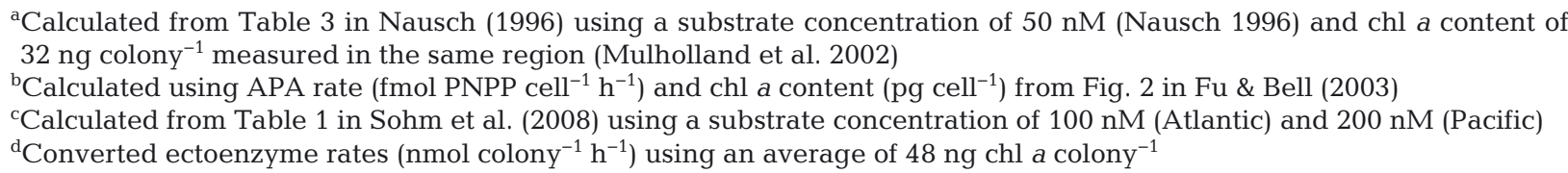 } \\
\hline
\end{tabular}


Krauk et al. 2006, White et al. 2006). Low cellular P in Trichodesmium was termed the 'P sparing effect' by Karl et al. (1992) as it was suggested that this is a specific cellular adaptation for growth of these cyanobacteria in P-depleted environments. The significance of Trichodesmium ectoenzyme activity in surface waters is high compared with seawater APA and LAP when colony abundance is at its seasonal peak at the BATS site (Table 3). As suggested by Smith et al. (1992) for marine snow, the significance of Trichodesmium APA and LAP can also be compared to seawater using a volume concentration factor (Table 3). This comparison assumes that the volume of the interstitial water in a marine snow aggregate is directly comparable to surrounding seawater on a per volume basis. If we apply the same logic to colonies of Trichodesmium, the volume displacement of the consortium of organisms associated with a cyanobacterial colony can be compared to the equivalent volume of seawater. The orders of magnitude higher APA and LAP activities associated with Trichodesmium (Table 3) suggest that the colonies are 'hotspots' and a source of regenerated $\mathrm{P}$ and $\mathrm{N}$ in surface waters at BATS.

\section{Inorganic $P$ and Leu incorporation by colonies of Trichodesmium}

Phytoplankton in P-limiting environments such as the Sargasso Sea depend heavily on regeneration of nutrients to sustain growth (Cotner et al. 1997, Rivkin \& Anderson 1997). The high capacity for organic phosphorus and nitrogen hydrolysis (Tables 2 \& 6) combined with a low affinity and apparent lack of competitive uptake of inorganic and organic nutrients (Table 4) suggest that nutrient regeneration by Trichodesmium colonies may be as important to the surrounding microplankton community as to the cyanobacteria themselves. The low level of both phosphate and leucine incorporation measured in association with the Trichodesmium colonies compared to seawater (Table 4) suggests that, on a shortterm temporal scale, the colonies are primarily a source of regenerated phosphate and nitrogen (Leu) to the surrounding microbial community. Since high rates of APA associated with the colonies will produce significant amounts of inorganic $\mathrm{P}$, our isotope dilutions may have been severely underestimated by only accounting for bulk dissolved phosphate in surface waters. Sañudo-Wilhelmy et al. (2004) found relatively high concentrations of $\mathrm{P}$ adsorbed to the surface of Trichodesmium colonies and Sohm \& Capone
(2006) estimated that an average of $8 \%$ of their Ptracer could be accounted for by adsorption. Therefore, in addition to $\mathrm{P}$ adsorption, we suggest that the comparatively low $\mathrm{P}$ and Leu tracer incorporation rates associated with Trichodesmium (Table 4) were caused by high APA and LAP rates diluting the existing $\mathrm{P}$ and Leu pools surrounding the colonies. The LAP measurements in this study are based on a model substrate (Leu-MCA) that will account for a number of proteases (Berges \& Falkowski 1996, Obayashi \& Suzuki 2005). Therefore, Leu can be only one out of a number of possible end products generated by an unknown number of enzymes and this makes it impossible to correct for isotope dilution in incorporation experiments (Table 4). The non-specific organic $\mathrm{P}$ hydrolysis by APA produces only 1 end-product, however: DIP. Until recently, P dilution caused by APA regeneration of organic P was not accounted for in isotope tracer studies. Sohm \& Capone (2006) and later Sohm et al. (2008) used APA rates to account for radioisotope tracer dilution of the inorganic P pool. These commendable efforts, however, do not take into account the unique APA enzyme saturation kinetics we observed in Trichodesmium colonies (Table 2). The mean $K_{\mathrm{m}}$ for Trichodesmium APA in this study (Table 2) suggest substrate saturations in the order of 40 to 160 times the concentrations used by Sohm \& Capone (2006) and Sohm et al. (2008). Therefore, if higher DOP concentrations are associated with the Trichodesmium colonies (higher than can be found in seawater alone) and these are not accounted for, accurate rates of radiotracer isotope dilutions can be severely underestimated. Due to the high rates of $\mathrm{P}$ and $\mathrm{N}$ regeneration associated with Trichodesmium colonies, conventional radioisotope incubations cannot be performed as is typically done in natural seawater.

\section{Ectoenzyme activity, an adaptive response to a changing environment}

The $V_{\max }$ rates of seawater APA in this study are similar to those in Cotner et al. (1997), who found higher maxima in spring. Cotner et al. (1997) suggested that the increase in seawater APA in spring was due to the intrusion of deep water with lower inorganic $\mathrm{P}$ relative to $\mathrm{N}$, resulting in P-limited growth. The highest $V_{\max }$ for seawater APA was recorded during spring in the upper $20 \mathrm{~m}$ of the water column in March 1993 (data not shown) and was associated with the annual primary production maximum measured concomitantly at the BATS site (Gundersen et al. 
2001). The spring bloom production maximum, followed by an increase in DOM excretion (Carlson et al. 1994) may imply that the measured increase in seawater APA is not only a product of P-stress (Hynes et al. 2009), but also a source dependent response to new production and increased availability of organic phosphorus. Recent studies have concluded that DOP, including phosphonates (Dyhrman et al. 2002, 2006), is a major source of $\mathrm{P}$ for Trichodesmium (Mulholland et al. 2002, Fu et al. 2005). This in turn suggests that APA associated with Trichodesmium is not necessarily indicative of a $\mathrm{P}$ 'stress' response only, but may also represent a DOP acquisition strategy that has developed in these cyanobacteria as an adaptation to a P-limited oligotrophic environment. The DOP pools at BATS ( $80 \mathrm{nM})$ are approximately an order of magnitude higher than the DIP pools (5 to 10 $\mathrm{nM}_{i}$ Wu et al. 2000, Cavender-Bares et al. 2001, Ammerman et al. 2003), suggesting that organic $P$ can be a significant source of $\mathrm{P}$ for the plankton community. Our measurements of APA associated with Trichodesmium colonies support this idea, as there was no seasonal maximum of activity in this changing environment, and the ectoenzyme activity was expressed throughout the year. The wide range in substrate $K_{\mathrm{m}}$ and $V_{\max }$ for both enzymes in seawater and in association with the Trichodesmium colonies (Table 2) may suggest that a number of different phosphatase and peptidases, with different substrate saturation kinetics, appeared during the course of a year at the BATS site. The variable saturation kinetics may be an adaptative response to a changing pool of organic $\mathrm{P}$ and $\mathrm{N}$, or due to changes in the seawater plankton community (Lamy et al. 1999), as well as species variability within the consortium of organisms in the Trichodesmium colonies.

\section{Summary}

Ectoenzyme activities associated with aggregates such as marine snow can be several orders of magnitude higher than the surrounding seawater (Amy et al. 1987, Karner \& Herndl 1992, Smith et al. 1992, Rath \& Herndl 1994), which is similar to the level of activity associated with Trichodesmium colonies found in this study. Measured ectoenzyme activities associated with Trichodesmium colonies are higher than in adjacent waters, and appear to be adjusted to substrate concentrations far exceeding bulk measurements in the surrounding seawater. Thus, the buoyant Trichodesmium colonies are an important site for regenerated nitrogen and phosphorus in the sea. Due to the high concentrations of regenerated dissolved $\mathrm{N}$ and $\mathrm{P}$ that can be associated with the colonies, the pools of nutrients will significantly influence the isotope dilution in conventional radioisotope incubations with Trichodesmium. This study suggests that Trichodesmium plays an important role in regenerated production of $\mathrm{P}$ and $\mathrm{N}$ in the nutrient depleted surface waters of the BATS site in summer and fall.

Acknowledgements. The Captains and crew of the RV 'Weatherbird II' and RV 'Cape Henlopen' are gratefully acknowledged for their assistance. Drs. A. H. Knap and A. F. Michaels are acknowledged for sharing ship time on BATS cruises between 1993 and 1997. D. Case is gratefully acknowledged for the analysis of particulate phosphate. The work was funded by NSF (OCE-9019415, OCE-9416614) to J.W.A., while support for K.M.O. and K.G. came from NSF grants OCE-9301950 and OCE-9617795 to A. H. Knap and A. F. Michaels.

\section{LITERATURE CITED}

Alldredge AL, Youngbluth MJ (1985) The significance of macroscopic aggregates (marine snow) as sites for heterotrophic bacterial production in the mesopelagic zone of the subtropical Atlantic. Deep-Sea Res 32: 1445-1456

Ammerman JW (1993) Microbial cycling of inorganic and organic phosphorus in the water column. In: Kemp PF, Sherr BF, Sherr EB, Cole JJ (eds) Handbook of methods in aquatic microbial ecology. CRC Press, Boca Raton, FL, p 649-660

Ammerman JW, Hood RR, Case DA, Cotner JB (2003) Phosphorus deficiency in the Atlantic: an emerging paradigm in oceanography. EOS Trans Am Geophys Union 84:165

- Amy PS, Caldwell BA, Soeldner AH, Morita RY, Albright LJ (1987) Microbial activity and ultrastructure of mineralbased marine snow from Howe Sound, British Columbia. Can J Fish Aquat Sci 44:1135-1142

> Azam F (1998) Microbial control of oceanic carbon flux: the plot thickens. Science 280:694-696

> Azam F, Long RA (2001) Sea snow microcosms. Nature 414: 495-498

Berges JA, Falkowski PG (1996) Cell-associated proteolytic enzymes from marine phytoplankton. J Phycol 32: 566-574

Borstad GA, Borstad LE (1977) The Oscillatoria erythraeum (Cyanophyta) community of associates. In: Stewart HB Jr (ed) Cooperative investigations of the Caribbean and adjacent regions II. FAO, Rome, p 51-57

> Capone DG, Drew Ferrier M, Carpenter EJ (1994) Amino acid cycling in colonies of the planktonic marine cyanobacterium Trichodesmium thiebautii. Appl Environ Microbiol 60:3989-3995

Carlson CA, Ducklow HW, Michaels AF (1994) Annual flux of dissolved organic carbon from the euphotic zone in the Sargasso Sea. Nature 371:405-408

> Carlson CA, Giovannoni SJ, Hansell DA, Goldberg SJ and others (2002) The effect of nutrient amendments on bacterioplankton production, community structure, and 
DOC utilization in the northwestern Sargasso Sea. Aquat Microb Ecol 30:19-36

- Caron DA, Lim EL, Sanders RW, Dennett MR, Berninger UG (2000) Responses of bacterioplankton and phytoplankton to organic carbon and inorganic nutrient additions in contrasting oceanic ecosystems. Aquat Microb Ecol 22: 175-184

Carpenter EJ, McCarthy JJ (1975) Nitrogen fixation and uptake of combined nitrogenous nutrients by Oscillatoria (Trichodesmium) thiebautii in the western Sargasso Sea. Limnol Oceanogr 20:389-401

Cavender-Bares KK, Karl DM, Chisholm SW (2001) Nutrient gradients in the western North Atlantic Ocean: relationship to microbial community structure and comparison to patterns in the Pacific Ocean. Deep-Sea Res 48: 2373-2395

> Christian J, Karl DM (1995) Bacterial ectoenzymes in marine waters: activity ratios and temperature responses in three oceanographic provinces. Limnol Oceanogr 40: 1042-1049

Christian J, Karl DM (1998) Ectoaminopeptidase specificity and regulation in Antarctic marine pelagic microbial communities. Aquat Microb Ecol 15:303-310

Chróst RJ, Velimirov B (1991) Measurement of enzyme kinetics in water samples: effect of freezing and soluble stabilizer. Mar Ecol Prog Ser 70:93-100

> Cotner JB, Ammerman JW, Peele ER, Bentzen E (1997) Phosphorus-limited bacterioplankton growth in the Sargasso Sea. Aquat Microb Ecol 13:141-149

> Dyhrman ST, Webb EA, Anderson DM, Moffett JW, Waterbury JB (2002) Cell-specific detection of phosphorus stress in Trichodesmium from the Western North Atlantic. Limnol Oceanogr 47:1832-1836

Dyhrman ST, Chappell PD, Haley ST, Moffett JW, Orchard ED, Waterbury JB, Webb EA (2006) Phosphonate utilization by the globally important marine diazotroph Trichodesmium. Nature 439:68-71

$>$ Dyhrman ST, Benitz-Nelson CR, Orchard ED, Haley ST, Pellichia PJ (2009) A microbial source of phophonates in oligotrophic marine systems. Nat Geosci 2:696-699

Elardo KM, Ammerman JW, Gundersen K (1994) Exoenzyme activity associated with Trichodesmium colonies. EOS Trans Am Geophys Union 75:111

Fu FX, Bell PRF (2003) Effect of salinity on growth, pigmentation, $\mathrm{N}_{2}$ fixation and alkaline phosphatase activity of cultured Trichodesmium sp. Mar Ecol Prog Ser 257: 69-76

Fu FX, Zhang Y, Bell PRF, Hutchins DA (2005) Phosphate uptake and growth kinetics of Trichodesmium (Cyanobacteria) isolates from the North Atlantic Ocean and the Great Barrier Reef, Australia. J Phycol 41:62-73

Glibert PM, Bronk DA (1994) Release of dissolved organic nitrogen by marine diazotrophic cyanobacteria, Trichodesmium spp. Appl Environ Microbiol 60:3996-4000

Gordon LI, Jennings JC Jr, Ross AA, Krest JM (1993) A suggested protocol for continuous flow automated analysis of seawater nutrients (phosphate, nitrate, nitrite and silicic acid) in the WOCE hydrographic program and the Joint Global Ocean Fluxes Study. In: WOCE operations manual, WOCE report no 68/91 revision 1, 1994. Woods Hole Oceanographic Institute, Woods Hole, MA

Grossart HP, Berman T, Simon M, Pohlmann K (1998) Occurrence and microbial dynamics of macroscopic organic aggregates (lake snow) in Lake Kinneret, Israel, in fall. Aquat Microb Ecol 14:59-67
Gundersen K, Orcutt K, Purdie DA, Michaels AF, Knap AH (2001) Particulate organic carbon mass distribution at the Bermuda Atlantic Time-series Study (BATS) site. DeepSea Res II 48:1697-1718

- Hansell DA, Carlson CA (2001) Biogeochemistry of total organic carbon and nitrogen in the Sargasso Sea: control by convective overturn. Deep-Sea Res II 48:1649-1667

Hollibaugh JT, Azam F (1983) Microbial degradation of dissolved proteins in seawater. Limnol Oceanogr 28: 1104-1116

Hoppe HG (1983) Significance of exoenzymatic activities in the ecology of brackish water: measurements by means of methylumbelliferyl-substrates. Mar Ecol Prog Ser 11: 299-308

> Hynes AM, Chappell PD, Dyhrman ST, Doney SC, Webb EA (2009) Cross-basin comparison of phosphorus stress and nitrogen fixation in Trichodesmium. Limnol Oceanogr 54:1438-1448

Karl DM, Knauer GA, Martin JH (1988) Downward flux of particulate organic matter in the ocean: a particle decomposition paradox. Nature 332:438-441

Karl DM, Letelier R, Hebel DV, Bird BF, Winn CD (1992) Trichodesmium blooms and new nitrogen in the north Pacific gyre. In: Carpenter E, Capone D, Rueter J (eds) Marine pelagic Cyanobacteria: Trichodesmium and other diazotrophs. Kluwer Academic Publishers, Dordrecht, p 219-237

> Karl DM, Letelier R, Hebel D, Tupas L, Dore J, Christian J, Winn CD (1995) Ecosystem changes in the North Pacific subtropical gyre attributed to the 1991-92 El Niño. Nature 373:230-234

Karner M, Herndl GJ (1992) Extracellular enzymatic activity and secondary production in free-living and marinesnow-associated bacteria. Mar Biol 113:341-347

> Kirchman D, K'ness E, Hodson R (1985) Leucine incorporation and its potential as a measure of protein synthesis by bacteria in natural aquatic systems. Appl Environ Microbiol 49:599-607

Kirchman DL, Murray RE, Hodson RE (1986) Rates of DNA and protein synthesis by heterotrophic bacteria in aquatic environments: a comparison between the thymidine and leucine approaches. In: Megusar F, Gantar M (eds) Perspectives in microbial ecology. Proceedings of the 4th International Symposium on Microbial Ecology. 24-29 Aug, 1986, Slovene Society for Microbiology, Ljublijana, p 631-637

- Krauk JM, Villareal TA, Sohm JA, Montoya JP, Capone DG (2006) Plasticity of N:P ratios in laboratory and field populations of Trichodesmium spp. Aquat Microb Ecol 42: 243-253

- Lamy F, Bianchi M, Wambeke FV, Sempere R, Talbot V (1999) Use of data assimilation techniques to analyze the significance of ectoproteolytic activity measurements performed with the model substrate MCA-Leu. Mar Ecol Prog Ser 177:27-35

- Letelier RM, Karl DM (1996) Role of Trichodesmium spp. in the productivity of the subtropical North Pacific Ocean. Mar Ecol Prog Ser 133:263-273

Letelier RM, Karl DM (1998) Trichodesmium spp. physiology and nutrient fluxes in the North Pacific subtropical gyre. Aquat Microb Ecol 15:265-276

Lohrenz SE, Knauer G, Asper VL, Tuel M, Michaels AF, Knap AH (1992) Seasonal and interannual variability in primary production and particle flux in the northwestern Sargasso Sea: U.S. JGOFS Bermuda Atlantic Time- 
Series. Deep-Sea Res 39:1373-1391

Luo H, Benner R, Long RA, Hu J (2009) Subcellular localization of marine bacterial alkaline phosphatases. Proc Natl Acad Sci USA 106:21219-21223

> Mague TH, Mague FC, Holm-Hansen O (1977) Physiology and chemical composition of nitrogen-fixing phytoplankton in the Central North Pacific Ocean. Mar Biol 41: 213-227

Martinez J, Azam F (1993) Aminopeptidase activity in marine chroococcoid cyanobacteria. Appl Environ Microbiol 59:3701-3707

Martinez J, Smith DC, Steward GF, Azam F (1996) Variability in ectohydrolytic enzyme activities of pelagic marine bacteria and its significance for substrate processing in the sea. Aquat Microb Ecol 10:223-230

McCarthy JJ, Carpenter EJ (1979) Oscillatoria (Trichodesmium) thiebautii (Cyanophyta) in the Central North Atlantic Ocean. J Phycol 15:75-82

Mills MM, Ridame C, Davey M, La Roche J, Geider R (2004) Iron and phosphorus co-limit nitrogen fixation in the eastern tropical North Atlantic. Nature 429:292-294

Mulholland MR, Glibert PM, Miné Berg G, Van Heukelem L, Pantoja S, Lee C (1998) Extracellular amino acid oxidation by microplankton: a cross-ecosystem comparison. Aquat Microb Ecol 15:141-152

Mulholland MR, Floge S, Carpenter EJ, Capone DG (2002) Phosphorus dynamics in cultures and natural populations of Trichodesmium spp. Mar Ecol Prog Ser 239: 45-55

Nausch M (1996) Microbial activities on Trichodesmium colonies. Mar Ecol Prog Ser 141:173-181

> Obayashi Y, Suzuki S (2005) Proteolytic enzymes in coastal surface seawater: significant activity of endopeptidases and exopeptidases. Limnol Oceanogr 50:722-726

Obernosterer I, Kawasaki N, Benner R (2003) P-limitation of respiration in the Sargasso Sea and uncoupling of bacteria from P-regeneration in size-fractionation experiments. Aquat Microb Ecol 32:229-237

Orchard ED, Webb EA, Dyhrman ST (2009) Molecular analysis of the phosphorus starvation response in Trichodesmium spp. Environ Microbiol 11:2400-2411

Orcutt KM (1999) Environmental factors regulating $\mathrm{N}_{2}$ fixation by Trichodesmium spp. in the Sargasso Sea. PhD thesis, University of Wales, Swansea

> Orcutt KM, Lipschultz F, Gundersen K, Arimoto R, Michaels AF, Knap AH, Gallon JR (2001) Seasonal pattern and significance of $\mathrm{N}_{2}$ fixation by Trichodesmium at the Bermuda Atlantic Time-series (BATS) site. Deep-Sea Res II 48:1583-1608

> Orcutt KM, Rasmussen U, Webb EA, Waterbury JB, Gundersen K, Bergman B (2002) Characterization of Trichodesmium spp. by genetic techniques. Appl Environ Microbiol 68:2236-2245

Paerl HW, Bebout BM, Prufert LE (1989) Bacterial associations with marine Oscillatoria sp. (Trichodesmium sp.) populations: ecophysical implications. J Phycol 25: 773-784

> Perry MJ (1976) Phosphate utilization by and oceanic diatom in phosphorus-limited chemostat culture and in the oligotrophic waters of the central North Pacific. Limnol Oceanogr 21:88-107

Post AF, Dedej Z, Gottlieb R, Li H and others (2002) Spatial and temporal distribution of Trichodesmium spp. in the stratified Gulf of Aqaba, Red Sea. Mar Ecol Prog Ser 239:241-250
Rath J, Herndl GJ (1994) Characteristics and diversity of $\beta$-D-glucosidase (EC 3.2.1.21) activity in marine snow. Appl Environ Microbiol 60:807-813

> Rath J, Schiller C, Herndl GJ (1993) Ectoenzymatic activity and bacterial dymanics along a trophic gradient in the Caribbean Sea. Mar Ecol Prog Ser 102:89-96

> Rivkin RB, Anderson MR (1997) Inorganic nutrient limitation of oceanic bacterioplankton. Limnol Oceanogr 42: 730-740

Sañudo-Wilhelmy SA, Kustka AB, Gobler CJ, Hutchins DA and others (2001) Phosphorus limitation by Trichodesmium in the Central Atlantic Ocean. Nature 411:66-69

Sañudo-Wilhelmy SA, Tovar-Sanchez A, Fu FX, Capone DG, Carpenter EJ, Hutchins DA (2004) The impact of surface-adsorbed phosphorus on phytoplankton Redfield stoichiometry. Nature 432:897-901

Sebastian M, Ammerman JW (2009) The alkaline phosphatase PhoX is more widely distributed in marine bacteria than the classical PhoA. ISME J 3:563-572

Sheridan CC, Steinberg DK, Kling GW (2002) The microbial and metazoan community associated with colonies of Trichodesmium spp.: a quantitative survey. J Plankton Res 24:913-922

Simon M, Grossart HP, Schweitzer B, Ploug H (2002) Microbial ecology of organic aggregates in aquatic ecosystems. Aquat Microb Ecol 28:175-211

Smith DC, Simon M, Aldredge AL, Azam F (1992) Intense hydrolytic enzyme activity on marine aggregates and implications for rapid particle dissolution. Nature 359: 139-142

Sohm JA, Capone DG (2006) Phosphorus dynamics of the tropical and subtropical north Atlantic: Trichodesmium spp. versus bulk plankton. Mar Ecol Prog Ser 317:21-28

Sohm JA, Mahaffey C, Capone DG (2008) Assessment of relative phosphorus limitation of Trichodesmium spp. in the North Pacific, North Atlantic, and north coast of Australia. Limnol Oceanogr 53:2495-2502

Sokal RR, Rohlf FJ (1969) Biometry. WH Freeman, New York, NY

Solorzano L, Sharp JH (1980) Determination of total dissolved phosphorus and particulate phosphorus in natural waters. Limnol Oceanogr 25:754-758

Somville M, Billen G (1983) A method for determining exoproteolytic activity in natural waters. Limnol Oceanogr 28:190-193

Stihl A, Sommer U, Post AF (2001) Alkaline phosphatase activities among populations of the colony forming diazotrophic cyanobacterium Trichodesmium spp. (Cyanobacteria) in the Red Sea. J Phycol 37:310-317

> Stoecker DK, Gustafson DE Jr (2003) Cell-surface proteolytic activity of photosynthetic dinoflagellates. Aquat Microb Ecol 30:175-183

Strickland JDH, Parsons TR (1972) A practical handbook for seawater analysis, Vol 167, 2nd edn. Bulletin of the Fisheries Research Board of Canada, Ottawa

> White AE, Spitz YH, Karl DM, Letelier RM (2006) Flexible elemental stoichiometry in Trichodesmium spp. and its ecolological implications. Limnol Oceanogr 51:1777-1790

Wu J, Sunda W, Boyle EA, Karl DM (2000) Phosphate depletion in the Western North Atlantic Ocean. Science 289: 759-762

Yentsch CM, Yentsch CA, Perras JP (1972) Alkaline phosphatase activity in the tropical marine blue-green alga, Oscillatoria erythraea (Trichodesmium). Limnol Oceanogr 17:772-774 